\title{
THE MOST IMPORTANT MOTIVATIONAL FACTORS FOR EMPLOYEES IN INDUSTRIAL ENTERPRISES REGARDING THE DIFFERENCES BETWEEN VARIOUS GENERATIONAL GROUPS
}

\author{
Miroslava MĹKVA ${ }^{1}$, Marta KUČEROVÁ ${ }^{1}$, Zdenka GYURÁK BABEL'OVÁ ${ }^{1}$ \\ ${ }^{1}$ SLOVAK UNIVERSITY OF TECHNOLOGY IN BRATISLAVA \\ FACULTY OF MATERIALS SCIENCE AND TECHNOLOGY IN TRNAVA \\ INSTITUTE OF INDUSTRIAL ENGINEERING AND MANAGEMENT \\ Ulica JÁnA BotTu 2781/25, 91724 TRNAVA, SlOVAK REPUBliC \\ e-mail: miroslava.mlkva@stuba.sk, marta.kucerova@stuba.sk, zdenka.babelova@stuba.sk \\ Received 15 April 2020, Accepted 2 May 2020, publisher 25 June 2020
}

\begin{abstract}
The paper presents results of the research focused on the coexistence of different generations of employees. Described in the paper is the importance of selected motivational factors and motivational needs fulfilment with respect to different generational groups of employees. The research was carried out at the University based on the data collection from business practice of industrial enterprises. The analysed data were collected in 2018, the total sample consisted of 534 respondents. The respondents were exclusively employees of industrial enterprises. Based on the processing, analysis and evaluation of the collected data, it is possible to draw some recommendations for the management of industrial enterprises, which has to continually face the question of how to approach staff management effectively. The research results are based on examination of different preferences of the employees from various generations, and they point at the need of taking into account the requirements and needs of employees, differentiated according to their age. Respecting these requirements will make possible for managers to take into account the specificities of employees of different ages, and to indicate the ways of effectively managing the age-diversified workforce.
\end{abstract}

Key words

Motivational factors, needs fulfilment, employees, generations

\section{INTRODUCTION AND THEORETICAL BACKGROUND}

Today, different generations of employees are involved in the work, with different labour market shares [1]. Each generation is characterized by different strengths, skills, experience and working habits. This may indicate a huge opportunity for the productivity and performance [2]. The management concept concerned with creating age-sensitive conditions at organizational level in managing work processes in the physical and social environment is known as Age 
management [3]. If business management is aware of the diversity and specifics of individual generations, they seek to build beneficial alliances between them, build mutual respect and share know-how before their differences could adversely affect corporate culture, reduce the motivation for performance of individuals or whole organization.

The oldest, still productive generation of "baby boomers" (people born in 1946-1960) are very loyal, considering work itself to be of the highest value. Work is important to them for financial security, not for self-realization or work enjoyment itself [4]. They expect their experience to be appreciated at work [5]. Older workers often have skills and qualifications that are difficult to acquire and that form the fundamentals of an organization's human resources; however, educational potential development shortages are often considered as one of the risks of employing older workers [6]. Owing to their experience and know-how, it is advisable to involve them in corporate education as mentors, or utilise their experience when creating training groups within organizational development programs, and also to consider their seniority in career planning.

Representatives of generations X (born 1961-1980) and Y (born 1981-1995) are considered as perseverant and creative. At work, they expect benefits that will help them maintain their higher standard of living and increase the efficiency of their work. They expect flexible working hours, above-standard education, work with a coach or mentor, and benefits such as a smartphone or a car. They expect to be respected, listened to and treated equally. At the same time, they expect to have time to devote themselves to their families and hobbies [7]. Therefore, it is appropriate to build for them an informal working environment with the possibility of self-realization and sufficient technological equipment.

What is more, Generation $\mathrm{Y}$ is considered to be highly educated, largely using different technologies [8]. Members of Generation Y perform best when they can share ideas, because they appreciate relationship and friendship. Therefore, they prefer teamwork and possibility to ask questions $[9,10]$. They require constant feedback and the opportunity to discuss the meaningfulness of the tasks assigned. They are willing to work hard, even if they do not enjoy their task, but await appreciation by the supervisor and the company management for their welldone job. On the other hand, older generations of "baby boomers" and X are more cautious in expressing their views, and they can sometimes take discussions with younger colleagues in person. This is related to the natural desire of older people to maintain their influence and desire of young people to increase their impact [11]. Generation Z (born in 1996-2009) appears to be the most independent but also influenced by peers and friends $[12,13]$. They prefer sufficient freedom in their work but also some kind of leadership [14, 15] or mentoring [16]. The generation gap often appears in the workplace and is perceived as a source of conflicts that in fact have nothing to do with the basic generation differences. Any positive or negative behaviour exists in people of all ages [11].

With a well-established know-how sharing system, the older generation is relieved of the worries of uselessness, and the younger generation take the value of older generation as well as respect to the generated knowledge and experience. And this creates mutual synergy and awareness of the benefits of each generation. At present, trends such as mixed working groups, multi-generation project teams, mentoring programs, and advising successful older entrepreneurs to younger start-ups are proved as very useful.

\section{MATERIALS AND METHODS}

Within the research project framework determination, the research team specified the motivational factors related to work, that can affect the performance of employees, and thus the sustainable performance of the company. Based on the known facts and theoretical background, we formulated research questions focused on the importance of motivational factors and the 
degree of needs fulfilment according to employees in industrial enterprises, with regard to the differences between various generational groups.

Research Question 1: How important are particular work-related motivational factors for different generations of employees in industrial enterprises?

Research Question 2: What is the needs fulfilment level for particular work-related motivational factors for different generations of employees in industrial enterprise?

Research Question 3: What are the differences between the importance and the needs fulfilment of motivational factors with respect to individual generational groups of employees?

Empirical data on this issue were obtained by a questionnaire survey. The questionnaire was distributed to employees of industrial enterprises in Slovakia in both printed and electronic forms. The sample consisted of 534 respondents of different ages, who were divided into four generational groups when summarizing the results.

The questionnaire was focused on the respondents' perception on the importance of determined work-related motivational factors and the degree of their needs fulfillment. When formulating the questions, 19 work-related factors that can affect both employee performance and business performance were defined. Respondents expressed their opinion on the importance of the factors and the degree of their needs fulfilment within the 5-degree Likert scale (from 1 to 5).

IBM SPSS 22.0 (Statistical Package for the Social Sciences) was used to summarize, process and analyse the collected data. Basic statistical characteristics (mean, median, mode, standard deviation) were used to evaluate research results. In order to analyse the collected data, we used inductive statistics methods (hypothesis testing, variance analysis and correlation analysis). Descriptive statistics tools (basic quantitative characteristics, tables and graphs) were used for interpretation of the results.

\section{RESEARCH RESULTS AND DISCUSSION}

The research sample consisted of employees of industrial enterprises of various sizes, who were assigned to four generational groups by age. Table 1 shows the representation of individual generations in the sample. The Table shows that the composition within generational groups is uneven, but we can say that the composition of respondents corresponds to the composition of generational groups on the labour market in Slovakia.

\begin{tabular}{|c|c|c|}
\hline Generation group & Absolute frequency & Relative frequency $(\%)$ \\
\hline Baby Boomers & 36 & $6.74 \%$ \\
\hline Generation X & 153 & $28.65 \%$ \\
\hline Generation Y & 323 & $60.49 \%$ \\
\hline Generation Z & 22 & $4.12 \%$ \\
\hline
\end{tabular}

The questionnaire contained 19 work-related motivational factors, which the research team identified as the basic aspects influencing effective mutual cooperation of employees. For each factor, respondents expressed the perceived importance and also the perceived level of workrelated needs fulfilment within the defined scale. 


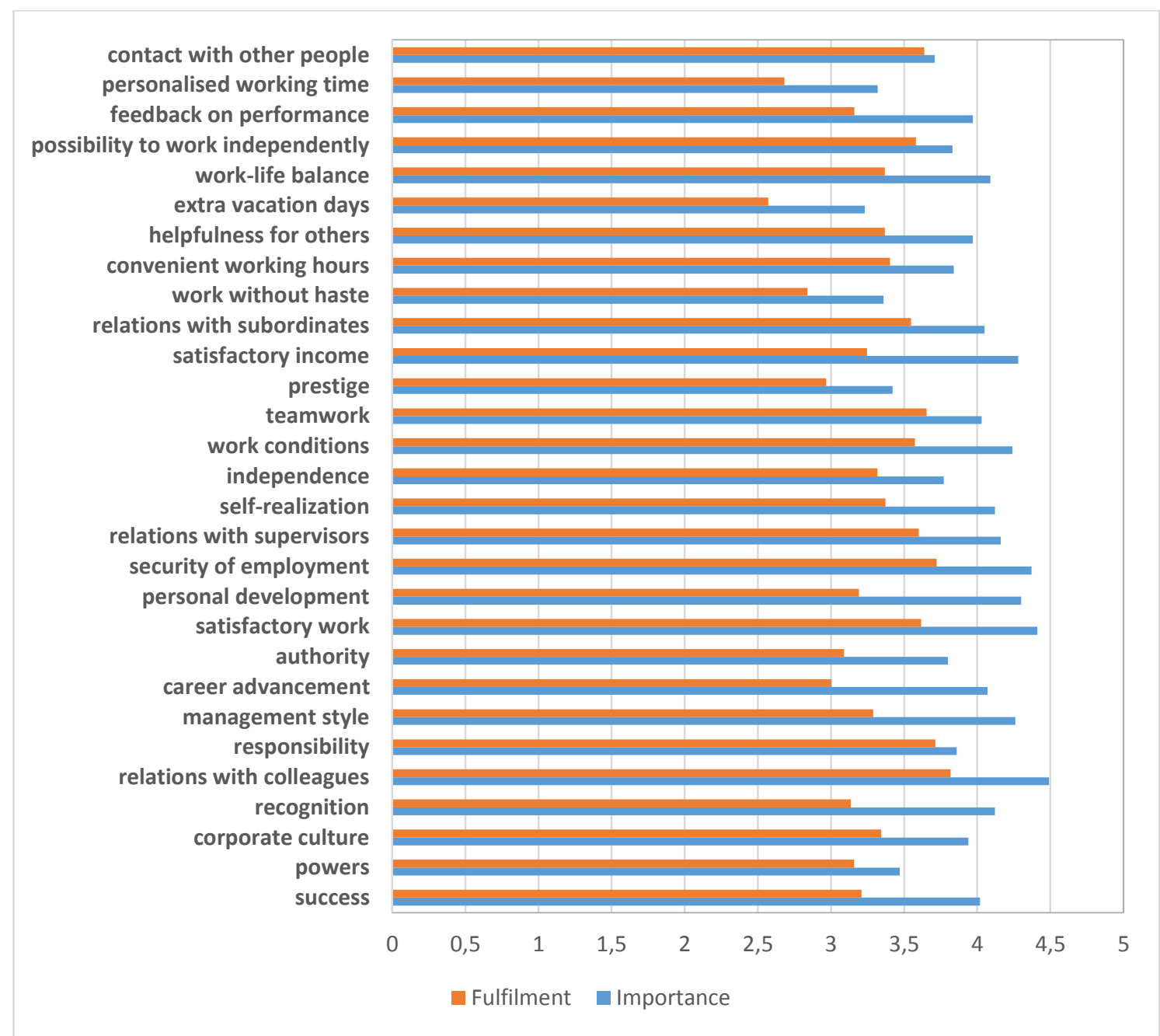

Figure 1 Importance of motivational factors and needs fulfilment (own elaboration, 2020)

The Figure 1 shows the average values of perceived importance of motivational factors and the average values of perceived needs fulfilment by employees in industrial enterprises summarized for the whole sample of respondents.

We also tested the significance of the difference between the perceived importance and the perceived needs fulfilment rate at the significance level of $5 \%$ for individual factors.

A random difference was shown only for the factor of "personal contact with other people" (probability $\mathrm{p}=0.3684$ ) and for the factor "to bear responsibility" (probability $\mathrm{p}=0.0707$ ).

As can be seen from graphical interpretation of results (Figure 1), less important motivational factors (average value of the importance is less than 3.5) for all employees are personalized working time (the possibility to choose hours or days you work), work without haste (work that does not need to be chased), extra vacation days and prestige.

Then, we focused on the working factors, which the respondents identified as the most important, and rated them as the most important.

Table 2 shows six motivational factors that are considered by all as well as individual generations to be the most important. The most important motivational factors are ranked in descending order.

Afterwards, we identified the most important motivational factors (Table 2). We could compare the importance of the motivational factors with the perceived level of needs fulfilment in relation to their work from the perspective of various generational groups. 


\begin{tabular}{|c|c|c|c|c|}
\hline All Generation & Baby Boomers & Generation X & Generation Y & Generation $\mathbf{Z}$ \\
\hline $\begin{array}{r}\text { Motivational factor/ } \\
\text { Rating }\end{array}$ & $\begin{array}{c}\text { Motivational factor/ } \\
\text { Rating }\end{array}$ & $\begin{array}{r}\text { Motivational factor/ } \\
\text { Rating }\end{array}$ & $\begin{array}{r}\text { Motivational factor/ } \\
\text { Rating }\end{array}$ & $\begin{array}{r}\text { Motivational factor/ } \\
\text { Rating }\end{array}$ \\
\hline $\begin{array}{l}\text { relations with } \\
\text { colleagues }\end{array}$ & $\begin{array}{ll}\text { relations with } \\
\text { colleagues } & 4.47 \\
\end{array}$ & $\begin{array}{ll}\text { relations with } \\
\text { colleagues } & 4.54 \\
\end{array}$ & $\begin{array}{l}\text { relations with } \\
\text { colleagues }\end{array}$ & $\begin{array}{l}\text { relations with } \\
\text { colleagues }\end{array}$ \\
\hline $\begin{array}{r}\text { satisfactory work } \\
4.41 \\
\end{array}$ & $\begin{array}{r}\text { satisfactory work } \\
4.36 \\
\end{array}$ & $\begin{array}{r}\text { satisfactory work } \\
4.44 \\
\end{array}$ & $\begin{array}{r}\text { personal development } \\
\mathbf{4 . 4 4} \\
\end{array}$ & $\begin{array}{r}\text { satisfactory work } \\
4.68 \\
\end{array}$ \\
\hline $\begin{array}{l}\text { security of } \\
\text { employment }\end{array}$ & $\begin{array}{l}\text { security of } \\
\text { employment }\end{array}$ & $\begin{array}{l}\text { security of } \\
\text { employment }\end{array}$ & $\begin{array}{l}\text { satisfactory work } \\
4.38 \\
\end{array}$ & $\begin{array}{l}\text { security of } \\
\text { employment }\end{array}$ \\
\hline $\begin{array}{l}\text { personal } \\
\text { development }\end{array}$ & teamwork & teamwork & $\begin{array}{l}\text { security of } \\
\text { employment }\end{array}$ & $\begin{array}{ll}\text { relations with } & \\
\text { supervisors } & 4.36 \\
\end{array}$ \\
\hline teamwork & $\begin{array}{ll}\text { relations with } \\
\text { colleagues } & 4.19 \\
\end{array}$ & $\begin{array}{r}\text { management style } \\
4.33 \\
\end{array}$ & teamwork & $\begin{array}{r}\text { satisfactory income } \\
4.32 \\
\end{array}$ \\
\hline $\begin{array}{r}\text { satisfactory income } \\
4.28\end{array}$ & $\begin{array}{l}\text { self-realization } \\
4.17\end{array}$ & $\begin{array}{r}\text { satisfactory income } \\
4.31 \\
\end{array}$ & $\begin{array}{r}\text { satisfactory income } \\
4.28\end{array}$ & $\begin{array}{r}\text { management style } \\
4.32\end{array}$ \\
\hline
\end{tabular}

Relations with colleagues (Figure 2) are considered by all groups of generations as the most important. The youngest generation perceives their needs fulfilment from this aspect at the highest level, while the post-war generation (Baby boomers) as the lowest one. This may be caused by a lack of appreciation of their experience and knowledge by other (maybe younger) colleagues.

Satisfactory work (Figure 3) - this factor is the most important for Generation Z. The degree of needs fulfilment related to this factor is approximately the same for all generations.

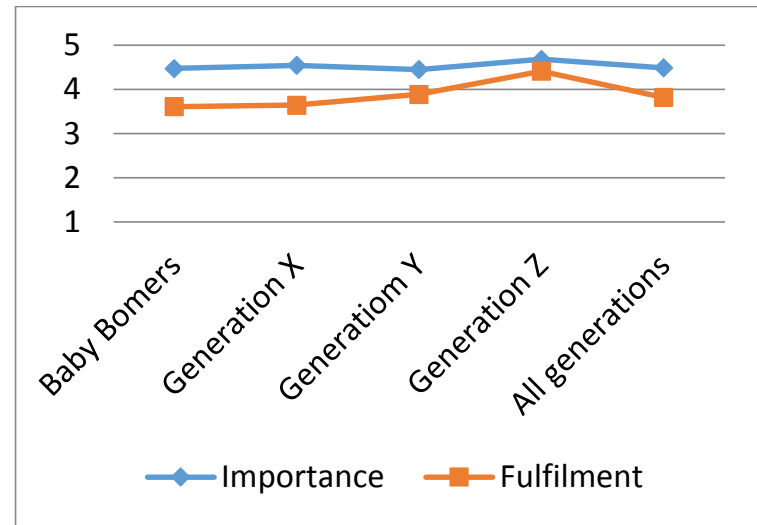

Figure 2 Relations with colleagues

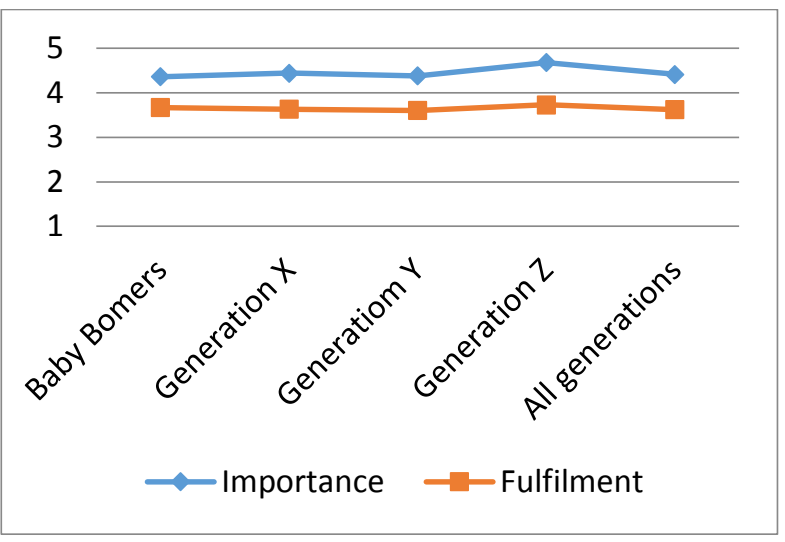

Figure 3 Satisfactory work

Security of employment (Figure 4) - the differences between the importance and the needs fulfilment of this factor are almost the same for all generations. Respondents from the Baby Boomers generation are least satisfied with fulfilling the job security needs; perhaps they feel threatened at work owing to their age.

Personal development (Figure 5) - based on the research results, this factor is considered to be the most important for Generation $\mathrm{Y}$, but there is a significant difference between importance and degree of their needs fulfilment. The greatest difference between the importance and the degree of needs fulfilment in the field of personal development is also evident in Generation $\mathrm{X}$ and Generation $\mathrm{Z}$. We can say that this is also because the representatives of Generation $Y$ consider this factor important, as most of them perceive not to be at the peak of their careers. Members of all generations seem to be not satisfied with their personal development opportunities. The smallest gap between this factor importance and its needs fulfilment was manifested by Generation of Baby Boomers. 


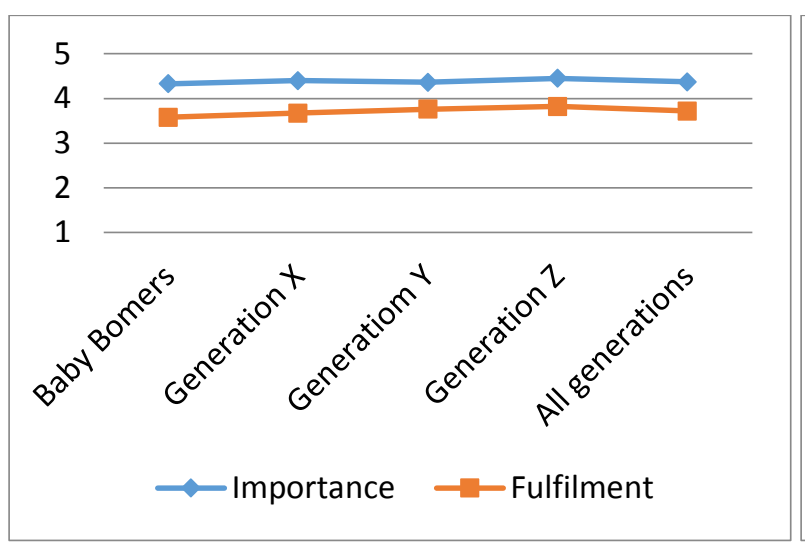

Figure 4 Security of employment

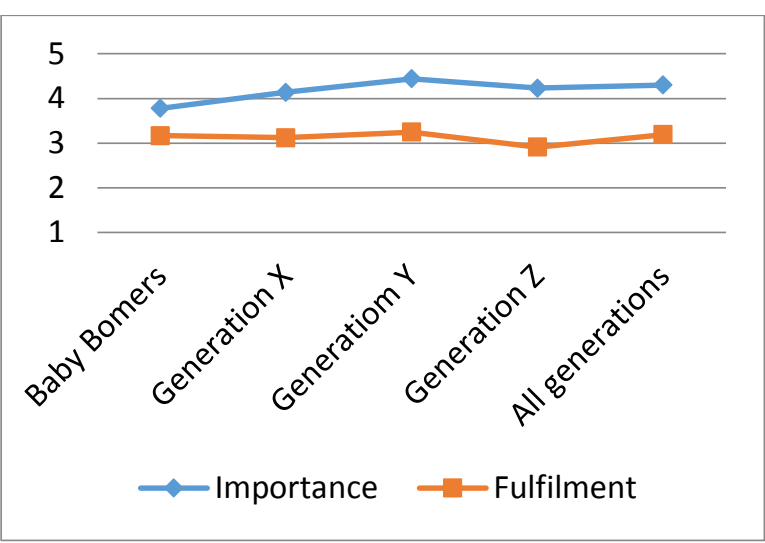

Figure 5 Personal development

The independent Global Study Workforce 2020 carried with the support of SAP and prepared by Oxford Eco Oxfordnomics suggests that many organizations fail to work with their human resources. They do not offer enough trainings in modern techno-techs, they do not develop talents and they are not able to ensure the meaningful transfer of knowledge among employees [17]. According to our research results, the needs fulfilment connected with personal development, the lowest level of its importance was demonstrated by Generation Z. We assume, that this is related to the fact that this generation is just entering the labour market and most of them are still in intensive process of personal development.

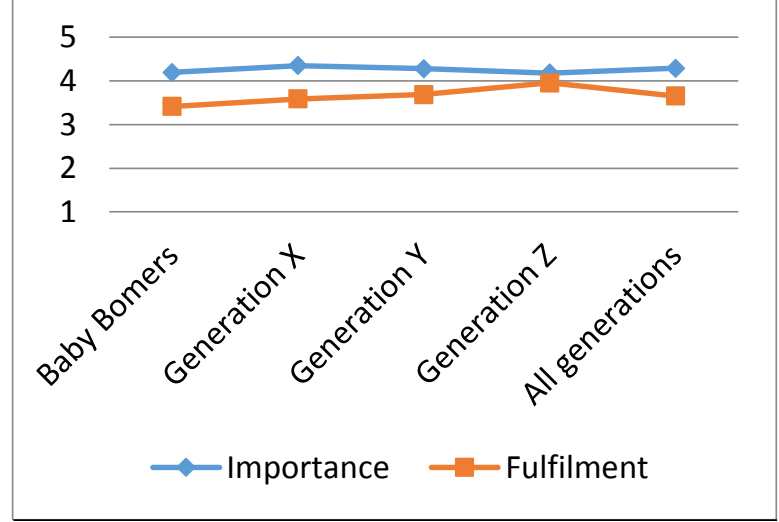

Figure 6 Teamwork

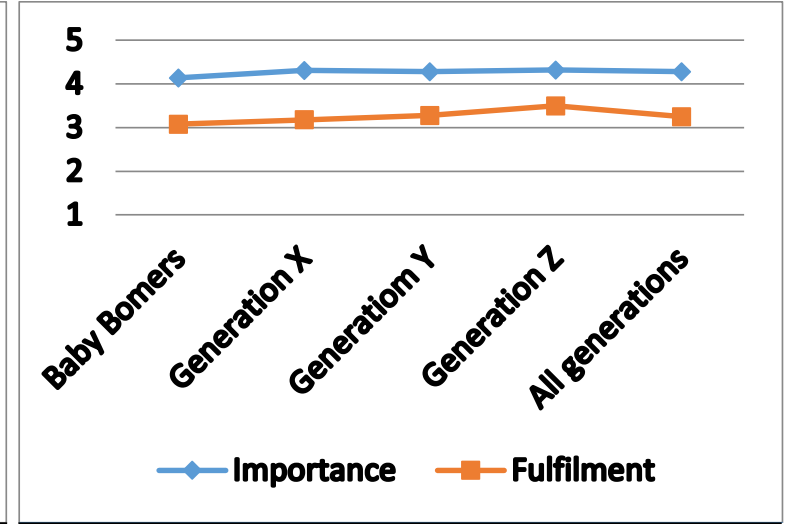

Figure 7 Satisfactory income

Teamwork (Figure 6) - it is interesting to note that the difference between this factor importance and level of needs fulfilment decreases from the oldest generation to the youngest generation Z, which perceives the level of fulfilment at the highest level compared to other generational groups.

Satisfactory income (Figure 7) - All generations perceive the importance of this factor almost equally, but the least importance was demonstrated by the Baby Boomers. All generations have shown a significant difference between the importance and the degree of needs fulfilment of this work factor. Regarding the rate of needs fulfilment connected to satisfactory income, the largest one was demonstrated by Generation $\mathrm{Z}$, and the lowest one was demonstrated by Baby Boomers.

Although comparison of generations brought interesting results, exploration of generations has its limitations. Constanza et al. agree that consensus regarding the annual intervals characterising individual generations/generation groups is quite limited. It also applies to the important shared experience characterising certain generation and its behaviour, as well as to 
the shared characteristics typical for individual generations, and the kind of behaviour resulting from the above-mentioned individual differences [18].

Also, some results suggest that generation differences are not the only factor influencing work attitudes; other factors comprise the national context and the life phase [19]. In any case, coexistence of different generations of employees is a challenge for employers. Only the employers who understand the importance of managing the age diversity in today's workplace can maximize the strengths of the employees' age diversity of the [20].

\section{CONCLUSION}

The aim of the presented research was to identify the factors that can positively or negatively affect cooperation or coexistence of employees of different generations in industrial enterprises. Presented results of the conducted research enabled the authors to recognize the defined work-related motivational factors the employees from various generations consider to be the most important, and how they perceive the level of their needs fulfilment in their organization in their current job position.

Based on empirical research, we can conclude that despite the differences between various generational groups, the relationships with colleagues are the most important for all generational groups. In addition to this important social aspect related to the social needs of people and in term of employment, employees from various generational groups perceive satisfactory work, security of employment, personal development, teamwork and satisfactory income as most important. In this paper, we focused in more detail on the factors that are perceived as the most important for employees in industrial enterprises. Subsequently, we compared the importance of these factors and the degree of needs fulfilment connected to these factors perceived by various generational groups in industrial enterprises in the Slovak Republic. Based on the results, we can conclude that the basic precondition for promoting intergenerational cooperation in organizations is, above all, the willingness to work with differences between generations and respect for their different life stages. Also important is the strengthening of mutual respect in the field of experience, values and attitudes and, in general, promotion of social tolerance. Understanding the generations, their preferences, values and attitudes can help managers to streamline approaches to their employees. Management of organizations should aim not only at ensuring the business performance, but also at creating conditions for positive coexistence of various generations.

\section{Acknowledgement}

The paper is a part of the VEGA project No. 1/0721/20 Identification of priorities for sustainable human resources management with respect to disadvantaged employees in the context of Industry 4.0.

\section{References}

[1] GYURÁK BABELOVÁ, Z., STAREČEK, A., CAGÁŇOVÁ, D., FERO, M., ČAMBÁL, M. 2019. Perceived Serviceability of Outplacement Programs as a Part of Sustainable Human Resource Management. In Sustainability, 11(17), pp. 1-21. ISSN 2071-1050 (2017: 2.075 - IF, 2 - JCR Best Q, 0.537 - SJR, Q2 - SJR Best Q). In database: DOI: 10.3390/su11174748; SCOPUS: 2-s2.085071989250.

[2] ČAMBÁL, M., URBANOVIČOVÁ, P., MIKULÁŠKOVÁ, J., SZABÓ, P. 2017. Koexistencia rôznych generácií zamestnancov - výzva pre súčasné priemyselné podniky (Coexistence of various employee generations - a challenge for the current industrial enterprises). Fórum manažéra, 2, 814. ISSN: $1336-7773$. 
[3] CIMBÁliKOVÁ L., et al. 2012. Age management pro práci s cílovou skupinou 50+ (Age management for the work with the target group of 50+), a methodology guide, 1 edition. Prague: Asociace institucí vzdělávání dospělých ČR (Association of institutions for education of adults). ISBN 978-80-904531-5-9

[4] FEENEY, P. 2015. The Baby Boomer Generation: A Lifetime of Memories; The History Press.

[5] GRAVETT, L., THROCKMORTON, R. 2007. Bridging the Generation Gap. How to Get Radio Babies, Boomers, Gen Xers, and Gen Years to Work Together and Achieve More, Career Press: Franklin Lakes, USA.

[6] NAEGELE, G. and WALKER, A. 2006. A guide to good practice in age management. Dublin/Ireland: European Foundation for the Improvement of Living and Working Conditions. [EReader Version]. Retrieved from http://www.eurofound.europa.eu/pubdocs/2005/137/en/1/ef05137en.pdf (retrieved 26.9.2019)

[7] TOLBIZE, A. 2008. Generational Differences in the Workplace. University of Minnesota, Research and Training Center on Community Living 2008. Available online: https://rtc.umn.edu/docs/2 18 Gen diff workplace.pdf

[8] BERKUP, S. B. 2014. Working with Generations X and Y in Generation Z period: Management of different Generations in business life. Mediterranean Journal of Social Sciences, 5, 1. doi: 10.5901/mjss.2014.v5n19p218.

[9] SHEAHAN, P. 2005. Generation Y: Thriving and Surviving with Generation Y at Work, 1st ed.; Hardie grant books: South Yarra, Australia.

[10] STARECEK, A., VRANAKOVA, N., KOLTNEROVA, K., CHLPEKOVA, A., CAGANOVA, D. 2017. Factors affecting the motivation of students and their impact on academic performance. Proceedings of the 14th International Conference on Efficiency and Responsibility in Education (ERIE). Prague, pp. 396-407.

[11] DEAL, J. J. 2007. Retiring the Generation Gap. How Employees Young and Old Can Find Common Ground. San Francisco: John Wiley \& Sons. ISBN-0-7879-8525-2

[12] GOH, E., JIE, F. 2019. To waste or not to waste: Exploring motivational factors of Generation Z hospitality employees towards food wastage in the hospitality industry. International Journal of Hospitality Management, 80, 126-135. https://doi.org/10.1016/j.ijhm.2019.02.005

[13] KAMENIDOU, I.C., MAMALIS, S.A., PAVLIDIS, S., BARA, E.Z.G. 2019. Segmenting the Generation Z Cohort University Students Based on Sustainable Food Consumption Behavior: A Preliminary Study. Sustainability 2019, 11, 837. https://doi.org/10.3390/su11030837

[14] CHO, M., BONN, M.A., HAN, S. J. 2018. Generation Z's Sustainable Volunteering: Motivations, Attitudes and Job Performance. Sustainability, 10, 1400. https://doi.org/10.3390/su10051400.

[15] MOHR, K.A.J., MOHR, E.S. 2017. Understanding Generation Z Students to Promote a Contemporary Learning Environment. Journal on Empowering Teaching Excellence, 1. doi: https://doi.org/10.15142/T3M05T.

[16] RODRIGUEZ, M., BOYER, S., FLEMING, D., COHEN, S. 2019. Managing the Next Generation of Sales, Gen Z/Millennial Cusp: An Exploration of Grit, Entrepreneurship, and Loyalty. Journal of Business-to-Business Marketing, 26, 43-55. doi: 0.1080/1051712X.2019.1565136.

[17] HR Pulse. 2014. Ako vnímajú HR riaditelia miléniovú generáciu a ako vníma zamestnanie ona? (How HR managers perceive the millennium generation and how the job is perceived by that generation). Prieskum spoločnosti PwC a biznis magazínu Profit. (A PwC and Profit Journal survey.) Published on 29/10/2014. www.pwc.com/sk/hr-pulse

[18] COSTANZA, D.P., BADGER, J.M., FRASER, R.L. et al. 2012. Generational Differences in Work-Related Attitudes: A Meta-analysis. J Bus Psychol 27, 375-394. https://doi.org/10.1007/s10869-012-9259-4

[19] EBERZ, F. 2020. "Generational Differences in the Workplace?: Let's Ask the Managers!." Global Applications of Multigenerational Management and Leadership in the Transcultural Era. IGI Global, 2020. 163-195. Web. 24 Mar. 2020. doi:10.4018/978-1-5225-9906-7.ch006

[20] MARTIN, C. A., TULGAN, B. 2002. Managing the Generation Mix: From Collision to Collaboration. $1^{\text {st }}$ ed.; HRD PRESS Amherst: Massachusetts, USA, pp. 1-121. ISBN 0-87425659-3 


\section{ORCID}

Miroslava Míkva

0000-0002-5769-7932

Marta Kučerová

0000-0002-0392-5805

Zdenka Gyurák Babel'ová

0000-0002-9927-3812 